\title{
In vitro evidence that the pastoral Artemisia campestris species exerts an anthelmintic effect on Haemonchus contortus from sheep
}

ARTICLE in VETERINARY RESEARCH COMMUNICATIONS · JULY 2014

Impact Factor: 1.24 · DOI: 10.1007/s11259-014-9609-y · Source: PubMed

READS

129

6 AUTHORS, INCLUDING:

\section{Fatma B chir}

Institut National de Recherche et d'Analyse...

14 PUBLICATIONS 81 CITATIONS

SEE PROFILE

Mohamed Aziz Darghouth

Université de la Manouba

78 PUBLICATIONS 702 CITATIONS

SEE PROFILE
Mourad Rekik

International Center for Agricultural Resear...

77 PUBLICATIONS 151 CITATIONS

SEE PROFILE

Mohamed Gharbi

Ecole Nationale de Médecine Vétérinaire

62 PUBLICATIONS 251 CITATIONS

SEE PROFILE 
In vitro evidence that the pastoral Artemisia campestris species exerts an anthelmintic effect on Haemonchus contortus from sheep

\section{Hafidh Akkari, Kais Rtibi, Fatma}

\section{B'chir, Mourad Rekik, Mohamed Aziz Darghouth \& Mohamed Gharbi}

Veterinary Research Communications An International Journal Publishing Topical Reviews and Research Articles on all Aspects of the Veterinary Sciences

ISSN 0165-7380

Vet Res Commun

DOI 10.1007/s11259-014-9609-y
VETERINARY

ONLINE FIRST

COMMUNICATIONS

An International Journal

Publishing Topical Reviews and

Research Articles on all aspects

of the Veterinary Sciences

\section{Springer}

\section{Springer}


Your article is protected by copyright and all rights are held exclusively by Springer Science +Business Media Dordrecht. This e-offprint is for personal use only and shall not be selfarchived in electronic repositories. If you wish to self-archive your article, please use the accepted manuscript version for posting on your own website. You may further deposit the accepted manuscript version in any repository, provided it is only made publicly available 12 months after official publication or later and provided acknowledgement is given to the original source of publication and a link is inserted to the published article on Springer's website. The link must be accompanied by the following text: "The final publication is available at link.springer.com". 


\title{
In vitro evidence that the pastoral Artemisia campestris species exerts an anthelmintic effect on Haemonchus contortus from sheep
}

\author{
Hafidh Akkari • Kais Rtibi • Fatma B'chir • \\ Mourad Rekik • Mohamed Aziz Darghouth • \\ Mohamed Gharbi
}

Accepted: 24 June 2014

(C) Springer Science+Business Media Dordrecht 2014

\begin{abstract}
Occurrence of anthelmintic resistant strains of helminths is increasing. The aim of this study was to evaluate the in vitro anthelmintic activity of Artemisia campestris in comparison to albendazole against Haemonchus contortus of sheep. In this respect, in vitro anthelmintic activities of crude aqueous and crude ethanolic extracts of aerial parts of A. campestris were investigated on eggs and adults of Haemonchus contortus. Chemical analyses revealed that overall profile of both extracts samples were dominated by flavonoids among them quercetin and apigenin derivatives were the most abundant phenolics constituents. Both extract types completely inhibited egg hatching at a concentration close to $2 \mathrm{mg} / \mathrm{ml}$. Lethal concentration $50 \%$ of $A$. campestris ethanolic and aqueous extracts were 0.83 and $1.00 \mathrm{mg} / \mathrm{ml}$ respectively $(p<0.05)$. The ethanolic extract showed better in vitro activity against adult parasites than the aqueous extract in terms of the paralysis and/or death of the worms at different hours posttreatment. Dose dependent activity was also observed for both extract. After 8 and $24 \mathrm{~h}$ of exposure, the ethanolic extract induced 91.3 and $100 \%$ mortality at the highest tested
\end{abstract}

H. Akkari $(\bowtie) \cdot$ M. A. Darghouth $\cdot$ M. Gharbi

Laboratoire de Parasitologie, Université de la Manouba,

École Nationale de Médecine Vétérinaire de Sidi Thabet,

2020 Sidi Thabet, Tunisia

e-mail: hafidh_akkari@yahoo.fr

K. Rtibi

Institut Supérieur de Biotechnologie de Béja, 9000 Béja, Tunisia

F. B'chir

Laboratoire des substances naturelles, Institut National de Recherche et d'Analyses Physico-Chimiques-Pôle Technologique de Sidi

Thabet, 2020 Sidi Thabet, Tunisia

M. Rekik

International Centre for Agricultural Research in the Dry Areas

(ICARDA), P.O. Box, 950764, Amman 11195, Jordan concentration respectively, while the aqueous extract induced 3.22 and $70.96 \%$ at the same concentration respectively.

To our knowledge, these results depict for the first time that A. campestris possesses in vitro anti-Haemonchus contortus properties.

Keywords Artemisia campestris · Anthelmintic . Haemonchus contortus $\cdot$ Tunisia

\section{Introduction}

Helminthoses represent a major constraint to the development of ruminant production, as they cause important financial losses particularly in areas where extensive grazing is practiced (Waller 1997). Gastrointestinal nematodes impair animal health welfare and productivity since they induce a decrease in meat production and reproduction and increase death rate (Hoste et al. 2005; Jabbar et al. 2006).

Commercial anthelmintics have been used for decades throughout the world to reduce the impact of helminths. Despite huge amounts of money spent worldwide to control these parasites, animal industry has not considerably benefited from the use of anthelmintics. Indeed, resistant parasite populations to several commercial anthelmintics are increasing, hence threatening field control of parasites (Jabbar et al. 2006). In several developing countries, small farmers have limited access to commercial anthelmintics and veterinary services due to their non-availability and/or to their high cost. These stockowners rely on the ethno-veterinary medicine as an alternative and a sustainable control option readily adaptable (Hussain et al. 2008; Al-Shaibani et al. 2009; Deeba et al. 2009; Sindhu et al. 2010) and such use underlines a rich background of indigenous knowledge that needs to be captured (Landau et al. 2014). Screening and proper assessment of the claimed effect on parasites and other animal diseases of 
some plant species could offer sustainable, accessible and environmentally acceptable alternatives.

Haemonchus contortus is one of the major gastrointestinal pathogens of small ruminants (O'Connor et al. 2006). This species was used by several authors to evaluate the anthelmintic effects of various medicinal plant species (Alawa et al. 2003; Assis et al. 2003; Hounzangbe-Adote et al. 2005; Eguale et al. 2006; 2007). Several methods are commonly used for testing nematicidal activity of both chemical and plant extract drugs. Amongst them, in vitro assays are relevant and cheaper than in vivo methods. Egg hatch assay (EHA) (Hubert and Kerboeuf 1984) is currently used for the detection of anthelmintic resistance in gastrointestinal nematodes (GIN) (Timothy et al. 2012). The adult worms motility (AWM) assays allow a more realistic evaluation of the in vivo nematicidal activity (Hounzangbe-Adote et al. 2005). These two tests are based on the hypothesis that in vitro nematicidal activity is indicative of a potential in vivo activity.

Artemisia campestris, commonly known as "tgouft" in Tunisia, is a perennial aromatic herb belonging to asteraceae family; it is widespread in Northern Africa and other similar Mediterranean agro-ecological zones and is commonly used as an herbal medicine. The leaves of this species are collected in summer and used in traditional medicine as decoction for their antispasmodic, anti-inflammatory, anti-rheumatic, antimicrobial, anthelmintic and anti-venin properties (Le floc'h 1983; Kotb 1985). Moreover, Ahmed et al. (2011) showed that ethanol; water infusion extracts and essential oil from A. campestris inhibit in vitro human adenocarcinoma cells. The phytochemical assessment of this species revealed the presence of tannins, polyphenols, flavonoids, saponosides and essential oils (Akrout 2005; Sefi et al. 2010). Different compounds have been isolated from the solvent (chloroform, hexane, and alcohol) extracts of this species such as flavonoids, chromones, and acetophenones (Tarhouni 1996; Vasconcelos et al. 1996). They are suspected to be the origin of the observed biological activities (Aniya et al. 2000; Memmi et al. 2007).

To our knowledge, there have been no published reports on the anthelmintic effects of this species. This study therefore aimed to test the in vitro anthelmintic efficacy, against $H$. contortus, of crude aqueous and ethanolic extracts of A. campestris aerial parts.

\section{Materials and methods}

Plant material and extracts preparation

Fresh leaves and stems of $A$. campestris were collected at Elhania, Sidi Bouzid governorate (Central Tunisia) during the spring season. The plant material was rinsed under running tap water then air dried at $50^{\circ} \mathrm{C}$ in a ventilated oven, until a constant weight was reached and finally ground up to a fine powder.

The crude aqueous and ethanolic extracts were used in the present trial. For this, $100 \mathrm{~g}$ of $A$. campestris powdered aerial parts were sequentially extracted by maceration in distilled water at room temperature $\left(20-25^{\circ} \mathrm{C}\right)$. The brew was collected and filtered with Whatman number one filter paper then lyophilized. For the ethanolic extract, $100 \mathrm{~g}$ of powdered plant were added to $500 \mathrm{ml}$ of $95^{\circ}$ ethanol then incubated at room temperature and frequently mixed. The solution was filtered through Whatman number one filter paper and finally, the solvent was evaporated in Rotavapor. The whole process was repeated 3 times ( $24 \mathrm{~h}$ for each). All extracts were concentrated, dried and kept in dark flask at $+4^{\circ} \mathrm{C}$ until used.

Analyses of aqueous and ethanolic plant extract composition

The chemical compositions of both A. campestris aqueous and ethanolic extracts were carried out by chromatography/mass spectrometry (HPLC/MS) analysis. HPLC-MS separation (series 1100, Agilent, Waldbronn, Germany) was performed using an Agilent C18 reversed-phase column $(150 \times 4.6 \mathrm{~mm})$ maintained at $33^{\circ} \mathrm{C}$ with a direct injection of $25 \mu \mathrm{l}$ of the extract, 100 bars pressure and $0.25 \mathrm{ml} / \mathrm{min}$ flow rate. A programmable variable wavelength UV detector was used for the analytic detection. Elution was performed by gradient mode using two mobile phases (A and B). Phase A solution consisted of water and acetic acid (999/1 v/v respectively), whilst phase B solution was acetonitrile. The gradient programme was chosen as follows: phase B was set at $5 \%$ during the 5 first minutes, increased linearly to $100 \%$ at $65 \mathrm{~min}$, remained at $100 \%$ for three minutes and decrease to $5 \%$ at $69 \mathrm{~min}$. Chromatographic peaks were integrated by Mass Lynx Software. The Mass spectroscopy (MS) was performed using a Micro mass Quattro Ultima PT MS model. The ion trap detector with electro-spray ionization (ESI) source was used for quantification in negative ionization mode under specific operating conditions (capillary voltage $(\mathrm{KV})$ : 3.20 ; capillary temperature (C): 300; multiplier (V): 550 cone gas flow (L/h): 60).

The identity of the components was assigned by comparison of their retention indices HPLC-MS spectra with commercially available standards from a homemade library or reported in the literature.

In vitro anthelmintic assays

The anthelmintic efficacy tests of the two plant extracts on $H$. contortus were performed using tow different procedures. For each assay, the eggs or adult worms were obtained from faeces and abomasum of Barbarine donor lambs aged 4 to 6 months and experimentally infected by oral administration of $6.000 \mathrm{H}$. contortus third stage larvae (L3). 


\section{Egg hatch assay}

The eggs used in the present assay were collected from previously mentioned donor sheep according to the guidelines of the World Association for the Advancement of Veterinary Parasitology (W.A.A.V.P.) (Timothy et al. 2012). After crushing the faeces in water, and successive siftings (300, 150,70 , and $38 \mu \mathrm{m}$ sieves), eggs were collected and centrifuged for $10 \mathrm{~min}$ at 2,500 $\mathrm{rpm}$. The supernatant was removed and a sodium chloride solution (density 1.2) was added. After homogenization, the mixture was centrifuged for $15 \mathrm{~min}$ at 3,000 rpm. The floating eggs were then extracted by pouring the supernatant on a $38 \mu \mathrm{m}$ sieve and abundant washing with distilled water.

Freshly collected eggs were incubated with different extracts in quadruplets. Leaves and stems $A$. campestris aqueous and ethanolic extracts were used as test treatment. Untreated eggs in Phosphate Buffered Saline (PBS) with Dimethyl sulfoxide (DMSO) $(0.5 \%)$ solution were used as negative control. Whilst, albendazole, reference drug (99.8\% pure standard reference, Médivét, S.A., Tunisia) was dissolved in DMSO and diluted at three concentrations $(0.25 ; 0.5$ and $1 \mu \mathrm{g} / \mathrm{ml})$; the latest served as positive control. For each extract concentration, approximately, 200 eggs in $1 \mathrm{ml}$ of PBS were placed in each test tube. Aqueous extracts at different concentrations $(2.0,1.0,0.5$ and $0.25 \mathrm{mg} / \mathrm{ml})$ in $1 \mathrm{ml}$ PBS were used. Ethanolic extracts, at the same concentrations, in a volume of $1 \mathrm{ml}$ in PBS with DMSO $(0.5 \%)$ were used. The test tubes were covered and incubated at $27^{\circ} \mathrm{C}$ for $48 \mathrm{~h}$. Hatched larvae (dead or alive) and unhatched eggs were counted under dissecting microscope at $40 \mathrm{x}$ magnification.

\section{Adult worms motility assay}

This test was performed according to Hounzangbe-Adote et al. (2005). Adult worms were collected from a lamb, at week 6 post-experimental infection. Immediately after being slaughtered, the abomasum was removed, opened and placed at $37^{\circ} \mathrm{C}, 9 \%$ sodium chloride solution. The collected parasites were then washed and kept in a PBS solution. Five to ten actively moving worms were placed in Petri dishes filled with $2.0,1.0$, and $0.5 \mathrm{mg} / \mathrm{ml}$ of $A$. campestris aqueous or ethanolic extracts in PBS or PBS with DMSO $(0.5 \%)$ respectively in a volume of $4 \mathrm{ml}$. Albendazole dissolved in DMSO then in PBS at a final concentration of $0.5 \mathrm{mg} / \mathrm{ml}$ was used as positive control. PBS with DMSO $(0.5 \%)$ was used as negative control. All the tests were performed in triplicates. Inhibition of worm motility was the criteria of anthelmintic activity. The required delays for larvae paralysis and/or complete immobility were recorded at $0 ; 4 ; 8$ and $24 \mathrm{~h}$. To test if the larvae could retrieve their motility after $24 \mathrm{~h}$, they were washed with distilled water and resuspended in PBS for $30 \mathrm{~min}$. Worms' death was ascertained by the absence of motility during an observation period of 5-6 s. The immobility index was calculated as follow:

Immobility index $(\%)=100 \times($ number of dead worms per Petri dish/total number of worms per Petri dish).

\section{Statistical analyses}

The statistical analyses were performed with SPSS-10.0 software package for Windows. Lethal concentration $50 \%\left(\mathrm{LC}_{50}\right)$ for egg hatch inhibition was calculated by probit analysis. Regression was used for evaluation of dose-response relationship using Minitab ${ }^{\circledR}$ Release 14. The result of the worm motility inhibition was expressed as mean \pm standard error of mean (S.E.M). Means of anthelmintic efficacy were compared by Student's test. A probability of 0.05 was used as a threshold for statistical significance.

\section{Results}

Chemical analysis of Artemisia campestris aqueous and ethanolic extracts

According to HPLC-MS analysis, a large part of phenolic compounds were assigned. Quercetin derivatives were the most abandon phenolic component in ethanolic extract. While, apigenin derivatives were the most abandon phenolic compounds identified in the aqueous extract (Table 1).

\section{Egg hatch assay}

Albendazole inhibited $92.05 \%$ of egg hatching at $1 \mu \mathrm{g} / \mathrm{ml}$ $\left(\mathrm{LC}_{50}=0.314 \mu \mathrm{g} / \mathrm{ml}\right)$. Crude ethanolic extract $\left(\mathrm{LC}_{50}=0.827\right.$

Table 1 Clause of major compounds in aqueous and ethanolic Artemisia campestris extracts (ranked in decreasing order) identified by Liquid Chromatography/Mass Spectrophotometry

\begin{tabular}{ll}
\hline Type of extract & Chemical component \\
\hline Aqueous extracts compounds & Quercetin \\
& 3 methyl- quercetin \\
7 methyl- quercetin \\
7 methyl - taxifolin \\
7,3 methyl- kaempferol \\
Apigenin-6,8- di C-glucoside \\
Ethanolic extracts compounds & Acethyl- luteolin- glucuronide \\
& Apigenin-7-glucoronide \\
& Hesperidin \\
& Luteolin \\
\hline
\end{tabular}


$\mathrm{mg} / \mathrm{ml}$ ) showed higher inhibitory effects than crude aqueous extract $\left(\mathrm{LC}_{50}=1.00 \mathrm{mg} / \mathrm{ml}\right)$ on egg hatching. The two extracts showed a statistically significant difference in their dosedependent ovicidal activity $(p<0.05)$ (Fig. 1; Table 2). The maximum concentration required to induce total $(100 \%)$ egg hatch inhibition for aqueous and ethanolic extracts was $2 \mathrm{mg} / \mathrm{ml}$ (Fig. 1)

\section{Adult worm motility}

Artemisia campestris crude ethanolic extract inhibited more worms than the aqueous extract in all tested concentrations. Dose dependent activity was also observed for both extracts. After 8 and 24h of exposure, the ethanolic extract induced 91.3 and $100 \%$ mortality at the highest tested concentration respectively, while the aqueous extract induced 3.22 and $70.96 \%$ at the same concentration respectively (Table 3). In addition, motility was higher with the crude aqueous extract treatment, as the worms survived for a significantly longer period in the presence of aqueous extract. This indicated that ethanolic extract has greater anthelmintic activity than the aqueous extract. There was $78 \%$ mortality of worms in albendazole within $8 \mathrm{~h}$ post-exposure. However, the worms in DMSO negative control solution showed neither paralysis nor mortality. Finally, no worm recovered motility in the PBS revival test.

\section{Discussion}

The current study is the first report of the anthelmintic activity of $A$. campestris species against $H$. contortus reducing egg hatching and adults' worm motility. The plant is an important pastoral species in arid rangelands and has several medicinal virtues.
Table 2 Dose-effect regression equations and determination coefficients of Artemisia campestris extracts on Haemonchus contortus egg hatching

\begin{tabular}{lll}
\hline Treatment & LC50 & $\begin{array}{l}\text { Regression equations and } \\
\text { determination coefficients }\left(\mathrm{R}^{2}\right)\end{array}$ \\
\hline Ethanolic extract & $0.827 \mathrm{mg} / \mathrm{ml}$ & $\mathrm{y} 1.869 \mathrm{e}^{0.810 \mathrm{x}}, \mathrm{R}^{2}=0.902$ \\
Aqueous extract & $1.00 \mathrm{mg} / \mathrm{ml}$ & $\mathrm{y}=4.392 \mathrm{e}^{0.606 \mathrm{x}}, \mathrm{R}^{2}=0.924$ \\
Albendazole & $0.314 \mu \mathrm{g} / \mathrm{ml}$ & $\mathrm{y}=4.385 \times+5,213, \mathrm{R}^{2}=0776$ \\
\hline
\end{tabular}

A large number of medicinal plants have been used to control parasitic infections in humans and animals (Luciana et al. 2013; Landolsi et al. 2013; Jyotsna et al. 2014). During preliminary screening of their anthelmintic activity, the majority of the researchers prefer in vitro tests including, larval (Perrett and Whitfield 1995) and adult (Parveen 1991) paralysis tests as well as egg hatching inhibition assays (Alawa et al. 2003), or biochemical tests (Khunkitti et al. 2000).

Artemisia campestris aqueous and ethanolic extracts totally inhibited $H$. contortus egg hatching at the concentration of $2 \mathrm{mg} / \mathrm{ml}$. Thymus capitatus (another important pastoral species form arid Tunisia) aqueous and ethanolic extracts totally inhibited $H$. contortus egg hatching at $2 \mathrm{mg} / \mathrm{ml}$ concentration (Landolsi et al. 2013). Eguale et al. (2007) reported that aqueous and hydro-alcoholic extract of Hedera helix induce complete (100\%) egg hatch inhibition at the same concentrations. Lower activity was observed for Spigelia anthelmia extracts on $H$. contortus egg hatching; it was effective at the concentration of $50 \mathrm{mg} / \mathrm{ml}$ (Assis et al. 2003). At the concentration of $10 \mathrm{mg} / \mathrm{ml}$, the seed ethanol extract of Mangifera indica revealed 91\% of effectiveness on $H$. contortus eggs (Costa et al. 2002). The aqueous extracts of Annona senegalensis seeds showed low $H$. contortus egg hatching inhibition activity $(11.5 \%)$ at the concentration of $7.1 \mathrm{mg} / \mathrm{ml}$ (Alawa et al. 2003).

Significant anthelmintic effects of both A. campestris extracts on adults $H$. contortus were observed in terms of worms'
Fig. 1 Dose-dependent profile of the percent hatching egg of Haemonchus contortus submitted to increasing concentrations of plant extracts $(0 ; 0.25 ; 0.5 ; 1$ and $2 \mathrm{mg} / \mathrm{ml})$

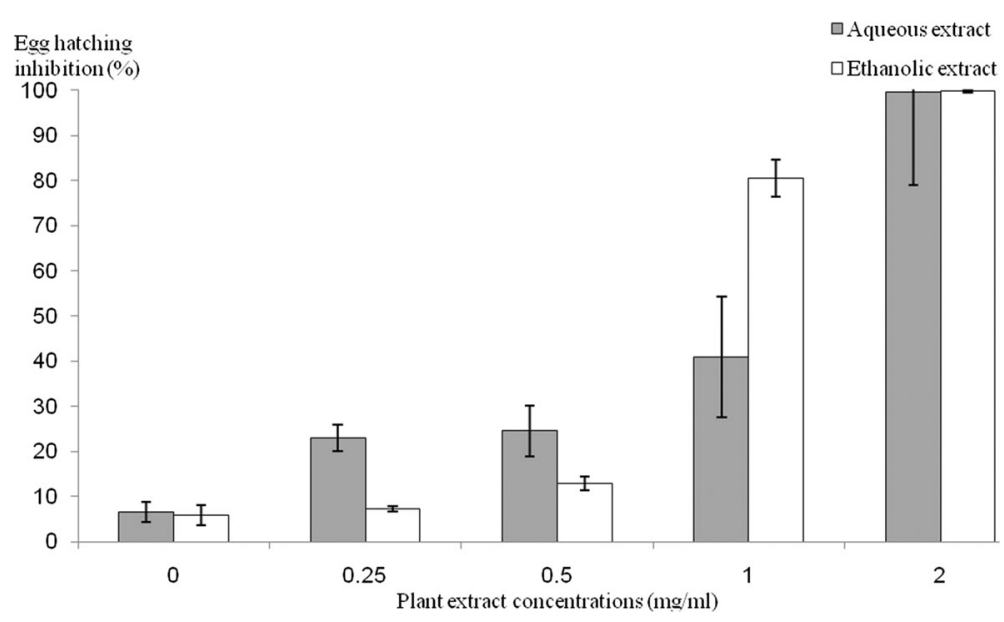


Table 3 In vitro anthelmintic efficacy of Artemisia campestris crude aqueous and ethanolic extracts on Haemonchus contortus

\begin{tabular}{|c|c|c|c|c|c|}
\hline \multirow[t]{2}{*}{ Treatment } & \multirow[t]{2}{*}{$\begin{array}{l}\text { Concentrations } \\
(\mathrm{mg} / \mathrm{ml})\end{array}$} & \multicolumn{4}{|c|}{$\begin{array}{l}\text { Mortality rate }(\%) \text { of Haemonchus contortus worms post-exposure to various } \\
\text { treatments (mean } \pm \text { SEM) }\end{array}$} \\
\hline & & $0 \mathrm{~h}$ & $4 \mathrm{~h}$ & $8 \mathrm{~h}$ & $24 \mathrm{~h}$ \\
\hline \multirow[t]{3}{*}{ Crude aqueous extract } & 0.5 & $0 \pm 0.00$ & $0 \pm 0.00$ & $2.85 \pm 0.06$ & $74.28 \pm 0.00$ \\
\hline & 1 & $0 \pm 0.00$ & $0 \pm 0.00$ & $3.22 \pm 0.07$ & $70.96 \pm 0.00$ \\
\hline & 2 & $0 \pm 0.00$ & $0 \pm 0.00$ & $3.22 \pm 0.07$ & $70.96 \pm 0.27$ \\
\hline \multirow[t]{3}{*}{ Crude ethanolic extract } & 0.5 & $0 \pm 0.00$ & $0 \pm 0.00$ & $62.96 \pm 0.21$ & $100 \pm 0.00$ \\
\hline & 1 & $0 \pm 0.00$ & $0 \pm 0.00$ & $74.19 \pm 0.16$ & $100 \pm 0.00$ \\
\hline & 2 & $0 \pm 0.00$ & $0 \pm 0.00$ & $91.30 \pm 0.14$ & $100 \pm 0.00$ \\
\hline Positive control (albendazole) & 0.5 & $0 \pm 0.00$ & $12.50 \pm 0.05$ & $78.04 \pm 0.06$ & $100 \pm 0.00$ \\
\hline Negative control (PBS with DMSO 0.5\%) & & $0 \pm 0.00$ & $0 \pm 0.00$ & $0 \pm 0.00$ & $16.12 \pm 0.07$ \\
\hline
\end{tabular}

paralysis and/or death at different post-treatment intervals and even low concentrations (91.3 and 3.2\% after $8 \mathrm{~h}$ post-exposure respectively in ethanolic and aqueous extract at $2 \mathrm{mg} / \mathrm{ml}$ ). Several studies revealed that the effect of plant extracts on adult worms can occur only at high concentrations. For example, Euphorbia helioscopia methanolic extract induces highest nematode immobility $(98 \%)$ at $50 \mathrm{mg} / \mathrm{ml}$ concentration (Bashir et al. 2012) while methanol extract of Artemisia brevifolia at concentration of $25 \mathrm{mg} / \mathrm{ml}$ is needed to induce significant in vitro anthelmintic activity on adult $H$. contortus. Aqueous extracts had no significant effect (Iqbal et al. 2004). In view of all these results in the literature, we put forward the statement that $A$. campestris was highly active against $H$. contortus egg hatching and worms' immobility.

It is generally considered that the plant extracts' anthelmintic proprieties are related to their content in condensed tannins (Akkari et al. 2008a, b; Hoste et al. 2006). Nevertheless, in vitro assays suggest that some other flavonoid molecules, e.g. flavonols or flavanols, might also possess anthelmintic properties (Molan et al. 2003, 2004; Barrau et al. 2005; Brunet and Hoste et al. 2006). The dose dependent relationship between the concentration of tannins and/or flavonoid compounds and the anthelminthic activity has been repeatedly demonstrated in both in vitro (Brunet and Hoste et al. 2006; Molan et al. 2002) and in vivo essays (Hoste et al. 2006; Terrill et al. 2009). It has been suggested that antioxidant flavonoids might have an anthelmintic activity (Ferreira 2011).

In the case of our study, it was revealed that profiles of both extracts samples were dominated by flavonoids; quercetin, apigenin and kempherol derivatives were the most abundant phenolic constituents (Table 1). Apigenin is one of important flavonoid, having a chemopreventive (Ruelia- de-Sousa et al. 2010) and antimicrobial activities (Palacios et al. 1983). Kaempferol and quercetin have a wide range of pharmacological activities including antioxidant, anti-inflammatory, antimicrobial and antiallergic activities (Shaik et al. 2006; Calderon-Montana et al. 2011). In addition, Lasisi and
Kareem (2011) reported that quercetin present in Bridelia ferruginea stem barks have an anthelmintic activity.

The results indicated that quercetin, apigenin and Kempherol are the probable active molecules of both plant extracts, but the considerable activity suggests a possible additive or synergistic relationship between these major components and the other plant extract components. Indeed, both extracts are a complex mixture of compounds that can interact with multiple molecular targets in various developmental parasites' stages.

The greater anthelmintic activity of crude ethanolic extract compared to crude aqueous extract could be due to a high concentration of alcohol soluble active anthelmintic molecules in A. campestris. Furthermore, the greater anthelmintic activity of the crude ethanolic extract in the current study could be due to easier and rapid transcuticular absorption of the ethanolic extract into the worms owing to the lipid soluble nature of the ethanolic extracts (Eguale et al. 2007).

Based on the results of the present study, it can be concluded that $A$. campestris crude aqueous and ethanolic extracts aerial parts showed significant in vitro dose-dependent activity against sheep $H$. contortus as ascertained by worm motility inhibition and egg hatching inhibition. Prior to in vivo trials, further in vitro trials at different concentrations against different worm species and stages are required to determine a more global anthelmintic activity of this plant species and its potential use in controlling small ruminants' gastrointestinal nematodes.

Acknowledgments This work received financial support by "Laboratoire d'Epidémiologie d'Infections Enzootiques des Herbivores en Tunisie" (Ministère de l'enseignement supérieur, Tunisia). We are grateful to Mr Limam Sassi, Mr Mohamed Jedidi, Mr Bechir Guesmi and Mr Tawfik Lahmar for their valuable technical assistance. We are grateful to Médivet S.A. Laboratories for kindly providing Albendazole.

Conflict of interest The authors have declared that no competing interests exist. The funder had no role in study design, data collection and analysis, decision to publish, or preparation of the manuscript. 


\section{References}

Ahmed A, Lidia AG, Hajer EJ, Pablo CM (2011) Antioxidant andantitumor activities of Artemisia campestris and Thymelae ahirsuta from southern Tunisia. Food Chem Toxicol 49:342347

Akrout, A (2005) Contribution à l'étude chimique et activités biologiques d'Artemisia campestris L., Thèse en Chimie, Faculté des Sciences de Sfax, Tunisia, 2005.

Akkari H, Dargouth MA, Ben Salem H (2008a) Preliminary investigation of the anti-nematode activity of Acacia cyanophylla Linl: excretion of gastrointestinal nematode eggs in lambs browsing A. cyanophylla with and without PEG or grazing native grass. Small Rumin Res 74: 78-83

Akkari H, Ben Salem H, Gharbi M, Abidi S, Darghouth MA (2008b) Feeding Acacia cyanophylla Lindl. Foliage to Barbarine lambs with or without PEG: effect on the excretion of gastro-intestinal nematode eggs. Anim Feed Sci Technol 147:182-192

Alawa CB, Adamu AM, Getu JO, Ajansui OJ, Abdu PA, Chiezey NP, Alawa JN, Bowman DD (2003) In vitro screening of two Nigeria medicinal plants (Vernonia amiygdalina and Annona senegalensis) for anthelmintic activity. Vet Parasitol 113:73-81

Al-Shaibani IRM, Phulan MS, Shiekh M (2009) Anthelmintic activity of Fumaria parviflora (Fumariaceae) against gastrointestinal nematodes of sheep. Int J Agric Biol 11:431-436

Aniya Y, Shimabukuro M, Shimoji M, Kohatsu M, Gyamfi MA, Miyagi C, Kunii D, Takayama F, Egashira T (2000) Antioxidant and hepatoprotective actions of the medicinal herb Artemisia campestris from the Okinawa Islands. Biol Pharm Bull 23:309-312

Assis LM, Bevilaqua CML, Morais SM, Vieira LS, Costa TC, Souza AL (2003) Ovicidal and larvicidal activity in vitro of Spigelia anthelmia Linn extracts on Haemonchus contortus. Vet Parasitol 117:43-49

Bashir AL, Chishti MZ, Fayaz AB, Hidayatullah T, Suhaib AB (2012) In vitro and in vivo anthelmintic activity of Euphorbia helioscopia L. Vet Parasitol 189:317-321

Barrau E, Fabre N, Fouraste I, Hoste H (2005) Effect of bioactive compounds from Sainfoin (Onobrychis viciifolia Scop.) on the in vitro larval migration of Haemonchus contortus: role of tannins and flavonol glycosides. Parasitol 131:531-538

Calderon-Montana JM, Burgos-Moron E, Perez-Guerrero C, LopezLazaro M (2011) A review on the dietary flavonoid Kaemferol. Mini-Rev Med Chem 11:298-344

Costa CTC, Morais SM, Bevilaqua CML, Souza MMC, Leite FKA (2002) Efei to ovicida de extratos de sementes de Mangifera indica L. sobre. Rev Bras Parasitol Vet 11:57-60 (in Portuguese)

Deeba F, Muhammad G, Iqbal Z, Hussain I (2009) Survey of ethnoveterinary practices used for different ailments in dairy animals in peri-urban areas of Faisalabad (Pakistan). Int J Agric Biol 11:535-541

Eguale T, Debella A, Feleke A (2006) In vitro anthelmintic activities of crude stem bark extracts of Albizia gummifera against Haemonchus contortus. Bull Anim Health Prod Afr 54:168-174

Eguale T, Tilahun G, Debella A, Feleke A, Makkonen E (2007) Haemonchus contortus: in vitro and in vivo anthelmintic activity of aqueous and hydro-alcoholic extracts of Hedera helix. Exp Parasitol 52:99-109

Ferreira, JFS (2011) Artemisia species in small ruminant production: their potential antioxidant and anthelmintic effects. Available from:www. ddr.nal.usda.gov/bistream/10113/42326/1/IND44379380.pdf.

Floc'h L (1983) Contribution à une étude ethno-botanique de la flore Tunisienne. Ministère de l'Enseignement Supérieur et de la recherche Scientifique, Tunis, Tunisia

Hoste H, Torres-Acosta JFJ, Paolini V, Aguilar-Caballero A, Etter E, Lefrileux Y, Chartier C, Broqua C (2005) Interactions between nutrition and gastrointestinal infections with parasitic nematodes in goats. Small Rumin Res 60:141-151
Hoste H, Jackson F, Athanasiadou S, Thamsborg SM, Hoskin SO (2006) The effects of tannin-rich plants on parasitic nematodes in ruminants. Trends Parasitol 22:253-261

Hounzangbe-Adote MS, Paolini V, Fouraste I, Moutairou K, Hoste $\mathrm{H}$ (2005) In vitro effects of four tropical plants on three life-cycle stages of the parasitic nematode, Haemonchus contortus. Res Vet Sci 78:155-160

Hubert J, Kerboeuf D (1984) A new method for culture of larvae used in diagnosis of ruminant gastrointestinal strongylosis: comparison with faecal cultures. Can J Comp Med 48:63-71

Hussain A, Khan MN, Iqbal Z, Sajid MS (2008) An account of the botan ical anthelmintics used in traditional veterinary practices in Sahiwal district of Punjab. Pakistan J Ethnopharmacol 119:185-190

Iqbal Z, Lateef M, Ashraf M, Jabbar A (2004) Anthelmintic activity of Artemisia brevifolia in sheep. J Ethnopharmacol 93:265-268

Jabbar A, Iqbal Z, Kerboeuf D, Muhammad G, Khan FMN, Afaq M (2006) Anthelmintic resistance: the state of play revisited. Life Sci 79:2413-2431

Khunkitti W, Fujimaki Y, Aoki Y (2000) In vitro antifilarial activity of extracts of the medicinal plant Cardiospermum halicacabuma gainst Brugia pahangi. J Helminthol 74:241-246

Kotb, HTF (1985) Medicinal Plants in Libya, Part II.

Landau, SY, Muklada, H, Abu-Rabia, A, Kaadan, S, Azaizeh, H (2014) Traditional Arab ethno-veterinary practices in small ruminant breeding in Israel. Small Ruminant Res 119:161-171

Landolsi MR, Akkar H, Bchir F, Gharbi M, Mhadhbi M, Aouadi S, Darghouth MA (2013) Thymus capitatus from Tunisian arid zone: chemical composition and in vitro anthelmintic effects on Haemonchus contortus. Vet Parasitol 197:374-378

Lasisi A, Kareem SO (2011) Evaluation of anthelmintic activity of stem bark extract and chemical constituents of Bridelia ferruginae (Benth) Euphorbiaceae. Afr J Plant Sci 5:469-474

Luciana MK, Jorge FSF, Javier MG, Anne MZ, David SL, Ana Carolina SC, Alessandro FTA (2013) Anthelmintic effect of plant extracts containing condensed and hydrolyzable tannins on Caenorhabditis elegans, and their antioxidant capacity. Vet Parasitol 18:218-227

Memmi A, Sansa G, Rjeibi I, El Ayeb M, Srairi-Abid N, Bellasfer Z, Fekhih A (2007) Use of medicinal plants against scorpionic and ophidian venoms. Arch Inst Pasteur Tunis 84:49-55

Molan AL, Waghorn GC, McNabb WC (2002) Effect of condensed tannins on egg hatching and larval development of Trichostrongylus colubriformis in vitro. Vet Rec 150:65-69

Molan AL, Meagher LP, Spencer PA, Sivakumaran S (2003) Effect of flavan-3-ol on in vitro egg hatching, larval development and viability of infective larvae of Trichostrongylus colubriformis. Int $\mathbf{J}$ Parasitol 33:1691-1698

Molan AL, Sivakumaran S, Spencer PA, Meagher LP (2004) Green tea flavan-3-ols and oligomeric proanthocyanidins inhibit the motility of infective larvae of Teladorsagia circumcincta and Trichostrongylus colubriformis in vitro. Res Vet Sci 77:239-243

O'connor LJ, Walkden-Brown SW, Kahn LP (2006) Ecology of the freeliving stages of major trichostrongylid parasites of sheep. Vet Parasitol 142:1-15

Palacios P, Gutkind G, Rondina R, de Torres R, Coussio J (1983) Genus Baccliaris II. Antimicrobial activity of B. crispa and B. notosergila. Planta Med 49:128

Parveen N (1991) Antifilarial activity of Vitex negundo against Setaria cervi. Fitoterapia 62:163-165

Perrett S, Whitfield PJ (1995) Atanine (3-dimethylallyl-4-methoxy-2quinolone), an alkaloid with anthelmintic activity from the Chinese medicinal plant Evodiarutae carpa. Planta Med 61:276-278

Ruelia- de-Sousa RR, Fuhler GM, Blom N, Ferreira CV, Aoyama H, Peppelenbosch MP (2010) Cytotoxicity of Apigenin on leukemia celllines: implications for prevention and therapy. Cell Death and Disease 1:1-11 
Sefi M, Fetoui H, Makni M, Zeghal N (2010) Mitigating effects of antioxidant properties of Artemisia campestris leaf extract on hyperlipidemia, advanced glycation end products and oxidative stress in alloxan induced diabetic rats. Food Chem Toxicol 48:1986-1993

Shaik YB, Castellani ML, Perrella A, Conti F, Salini V, Tete S, Madhappan B, Vecchiet J, De Lutiis MA, Caraffa A, Cerulli G (2006) Role of Quercitin (a natural herbal compound) in allergy and inflammation. J. Biol Regul Homeost Agents 20: $47-52$

Sindhu ZUD, Iqbal Z, Khan MN, Jonsson NN, Siddique M (2010) Documentation of ethno-veterinary practices used for treatment of different ailments in selected a hilly area of Pakistan, 201x. Int J Agric Biol 12:353-358
Tarhouni MR (1996) Isolation and characterization of flavonoids from Artemisia campestris L. subsp Glutinosa plant. J Soc Chim Tunis 12:891-894

Terrill TH, Dykes GS, Shaik SA, Miller JE, Kouakou B, Kannan G, Burke JM, Mosjidis JA (2009) Efficacy of Sericea lespedeza hay as a natural dewormer in goats: dose titration study. Vet Parasitol 163:52-56

Timothy G, Geary Barry C, Hosking Philip J, Samson-Himmelstjerna Skuce G, Maeder S, Holdsworth P, Pomroy W, Vercruysse J (2012) World Association for the Advancement of Veterinary Parasitology (WAAVP) Anthelmintic combination products targeting nematode infections of ruminants and horses. Vet Parasitol 190:306-316

Waller P (1997) Sustainable helminth control of ruminants in developing countries. Vet Parasitol 71:195-207 